University of Pennsylvania Carey Law School

Penn Law: Legal Scholarship Repository

Faculty Scholarship at Penn Law

$1-1-2011$

\title{
Fatal Invention: How Science, Politics, and Big Business Re-create Race in the Twenty-first Century
}

Dorothy E. Roberts

University of Pennsylvania Carey Law School

Follow this and additional works at: https://scholarship.law.upenn.edu/faculty_scholarship

Part of the Bioethics and Medical Ethics Commons, Civil Rights and Discrimination Commons, Health Law and Policy Commons, Medical Jurisprudence Commons, and the Science and Technology Law Commons

\section{Repository Citation}

Roberts, Dorothy E., "Fatal Invention: How Science, Politics, and Big Business Re-create Race in the Twenty-first Century" (2011). Faculty Scholarship at Penn Law. 433.

https://scholarship.law.upenn.edu/faculty_scholarship/433

This Article is brought to you for free and open access by Penn Law: Legal Scholarship Repository. It has been accepted for inclusion in Faculty Scholarship at Penn Law by an authorized administrator of Penn Law: Legal Scholarship Repository. For more information, please contact PennlawIR@law.upenn.edu. 


\section{FATAL INVENTION}

How Science, Politics, and Big Business
Re-create Race in the Twenty-first Century

Dorothy Roberts

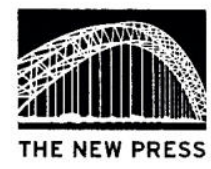




\section{Preface}

The principal human races presumably emerged as the populations of each continent responded to different evolutionary pressures.

-Nicholas Wade, "A New Look at Race and Natural Selection,"

New York Times, April 2, 2009.

The Food and Drug Administration (FDA) approved BiDil, a drug for the treatment of heart failure in self-identified black patients, representing a step toward the promise of personalized medicine.

-FDA News Release, June 23, 2005.

To chip away at an overwhelming budget deficit, Miami's public hospital system stopped paying for kidney dialysis for the indigent this week, officials said, leaving some patients to rely on emergency rooms for their life-sustaining treatments.

-Kevin Sack, "Hospital Cuts Dialysis Care for the Poor in Miami," New York Times, January 8, 2010.

In the agency's confidential files was a jail video showing Mr. Bah face down in the medical unit, hands cuffed behind his back, just before medical personnel sent him to a disciplinary cell. The tape shows him crying out repeatedly in his native Fulani, "Help, they are killing me!"

-Nina Bernstein, "Officials Obscured Truth of Migrant Deaths in Jail," New York Times, January 10, 2010. 
News stories about race, genetics, life, and death in the first decade of the twenty-first century reflect an ominous trend overtaking the social and political life of this nation. We are witnessing the emergence of a new form of racial politics in America, in which the state's power to control the life and death of populations relies on classifying them by race. Defining the political system of race in biological terms has been a constant feature of U.S. society for centuries, but the precise mechanisms for re-creating race have changed to reflect current sociopolitical realities. This book examines the role of genomic science and biotechnologies in today's reinvention of our enduring racial order.

The emerging biopolitics of race has three main components. First, some scientists are resuscitating biological theories of race by using cutting-edge genomic research to modernize old racial typologies that were based on observations of physical differences. Science is redefining race as a biological category written in our genes. Second, the biotechnology and pharmaceutical industries are converting the new racial science into products that are developed and marketed according to race and that incorporate assumptions of racial difference at the genetic level. Finally, government policies that are officially color-blind are stripping poor minority communities of basic services, social programs, and economic resources in favor of corporate interests while simultaneously imposing on these communities harsh forms of punitive regulation. These dehumanizing policies of surveillance and control are made invisible to most Americans by the emerging genetic understanding of race that focuses attention on molecular differences while obscuring the impact of racism in our society.

Only a decade ago, the biological concept of race seemed finally to have met its end. The Human Genome Project, which mapped the entire human genetic code, proved that race could not be identified in our genes. On June 26, 2000, when President Bill Clinton unveiled the draft genomic sequence, he famously declared that "human beings, regardless of race, are 99.9 percent the same." Contrary to popular misconception, we are not naturally divided into genetically identifiable racial groups. Biologically, there is one human race. Race applied to human beings is a political division: it is a system of governing people that classifies them into a social hierarchy based on invented biological demarcations.

But reports of the demise of race as a biological category were premature. 
Instead of hammering the last nail in the coffin of an obsolete system, the science that emerged from sequencing the human genome was shaped by a resurgence of interest in race-based genetic variation. Some scientists are claiming that clusters of genetic similarity detected with novel genomic theories and computer technologies correspond to antiquated racial classifications and prove that human racial differences are real and significant. Others are searching for genetic differences among races that can explain staggering inequalities in health and disease as well as variations in drug response.

There has been a corresponding explosion of race-based biotechnologies. In 2005, the U.S. Food and Drug Administration (FDA) approved the first race-specific drug, BiDil, to treat heart failure in black patients. Fertility clinics solicit egg donations on the basis of race and use race in genetic tests to determine which embryos to implant and which to discard. Consumers can send cheek swabs to dozens of online companies to find out not only their genetic ancestry, but also their racial identity. Some law enforcement agencies are using these same forensic tools to identify the race of suspects. And federal and state agents are starting to collect DNA from everyone they arrest, even those never charged with or convicted of a crime, filling ever-expanding government gene banks with compelled samples mostly from black and brown men.

The new science and technology of racial genetics threatens to steer America on a course of social inhumanity that already has begun to dominate politics in this century. Government policies that have drastically slashed social services have been accompanied by particularly brutal forms of regulation of racial minorities: mass imprisonment at rates far exceeding any other place on Earth or any time in the history of the free world; roundup and deportation of undocumented immigrants, often tearing families apart; abuse of children held in juvenile detention centers or locked up in adult prisons, some for the rest of their lives; official and unofficial infliction of torture in police stations and prison cells; and rampant medical neglect that kills.

Today, many Americans believe that the election of Barack Obama as president ushered in a new "postracial" society of equality, harmony, and opportunity. How can the perception of increasing racial fairness coexist with the reality of increasing racialized brutality? At the very moment that race consciousness is intensifying at the molecular level, it is fading at the social level. Genomic science is reinforcing the concept of race as a biological category even as Americans ignore the devastating effects of racial inequality on 
our society. I argue that this paradox reflects the primary impact of the new biopolitics of race: the seemingly color-blind regime of coercive surveillance imposed on poor communities of color will seem more acceptable to a majority of Americans as their belief in intrinsic racial differences is validated by genomic science and technologies. The new racial biopolitics obscures this modern form of state brutality at a time when the United States claims to have moved beyond violent enforcement of racial hierarchies. As biological theories of race have always accomplished, the redefinition of race as a genetic category and the technologies it is generating make racial inequality, as well as the punitive apparatus that maintains it, seem perfectly natural.

Despite claims that genomic scientists are reconfiguring race in a more precise and accurate way, I have found rampant confusion about this new racial science among friends and colleagues trying to understand where it fits in their conceptions of humanity and social equality. What is the value and impact of modernizing racial classifications with new genomic technology? Will this new understanding of race provide the answers we need to solve the problem of persistent racial inequality in our society?

When I first began reading about scientific discoveries that purported to validate the biological reality of race, I wondered how the claims could be true. My parents, to whom this book is dedicated, taught me that there is only one human race. This has meant more than words to me since childhood. As a scholar and activist, I have studied and seen firsthand the injustices made possible by separating people into different kinds of human beings. I undertook this book project as a personal challenge to my conviction that race is a political system. Would my own racial beliefs withstand my interviews with genomic researchers, the enthusiasm of many African Americans for tracing their genetic ancestry, and arguments by political activists who believe race-based biotechnologies are promoting health?

After five years of intense research and soul-searching, I found not one shred of evidence to counter my belief in the political nature of race. In fact, my journey only strengthened my understanding of our common humanity and the dehumanizing consequences of believing in innate racial differences. The answer to the problem of race will not be found in our genes. Yes, human beings are remarkably similar at the genetic level. But what should link us together is not our genetic unity; we should be bound by a common struggle for the equal dignity of all of humankind. 